\title{
Differential Thermal Evolution between Oil and Source Rocks in the Carboniferous Shale Reservoir of the Qaidam Basin, NW China
}

\author{
Qianru Wang ${ }^{1}$, Haiping Huang ${ }^{1,2, *}$, Chuan $\mathrm{He}^{3}$ and Zongxing $\mathrm{Li}^{4}$ \\ 1 Department of Geoscience, University of Calgary, Calgary, AB T2N 1N4, Canada; qrwang@outlook.com \\ 2 School of Geosciences, Yangtze University, Wuhan 430100, China \\ 3 Wuxi Research Institute of Petroleum Geology, Petroleum Exploration and Production Research Institute, \\ SINOPEC, Wuxi 214126, China; hechuan@cugb.edu.cn \\ 4 The Key Laboratory of Shale Oil and Gas Geological Survey, Institute of Geomechanics, Chinese Academy of \\ Geological Sciences, Beijing 100081, China; lizongxing@cags.ac.cn \\ * Correspondence: huah@ucalgary.ca
}

check for updates

Citation: Wang, Q.; Huang, H.; He, C.; Li, Z. Differential Thermal Evolution between Oil and Source Rocks in the Carboniferous Shale Reservoir of the Qaidam Basin, NW China. Energies 2021, 14, 7088. https://doi.org/10.3390/en14217088

Academic Editor: Reza Rezaee

Received: 1 October 2021

Accepted: 25 October 2021

Published: 29 October 2021

Publisher's Note: MDPI stays neutral with regard to jurisdictional claims in published maps and institutional affiliations.

Copyright: (c) 2021 by the authors. Licensee MDPI, Basel, Switzerland. This article is an open access article distributed under the terms and conditions of the Creative Commons Attribution (CC BY) license (https:/ / creativecommons.org/licenses/by/ $4.0 /)$.

\begin{abstract}
Shale oil and source rock samples of the Carboniferous Keluke Formation from well Chaiye 2 in the Delingha Depression were analyzed by gas chromatography-mass spectrometry. Source rocks were highly mature at the gas generation stage with vitrinite reflectance (Ro) of $1.45-1.88 \%$. However, the oil produced from the shale reservoir was characterized by abundant biomarkers but low abundance of diamondoid hydrocarbons with estimated Ro of ca. $0.78 \%$, indicating hydrocarbons were still at a relatively low thermal maturity level. As the crude oil was generated and accumulated autochthonously, preliminary results indicate that crude oil and source rocks witnessed differential thermal evolution and significant disparity of the current thermal maturity in the shale reservoir due to rapid tectonic subsidence and clay mineral catalysts that accelerated the thermal maturation process. Although tectonic uplifts occurred afterwards, the vitrinite recorded the highest maturity that source rocks have ever reached, whereas the oil has not reached the same maturity level due to less impact from thermal alteration or mineral catalysis than source rocks in the shale reservoir. Such a discovery enlarges the hydrocarbon perseveration of maturity ranges in reservoirs, particularly for the unconventional tight formation, and benefits potential hydrocarbon exploration from highly mature sediments.
\end{abstract}

Keywords: thermal maturity; differential evolution; biomarkers; diamondoid hydrocarbons; clay catalysis; Qaidam Basin

\section{Introduction}

The Qaidam Basin, with an area of $121,000 \mathrm{~km}^{2}$, is the largest intermontane basin of the northeastern Tibetan Plateau, and a prolific hydrocarbon production province. Hydrocarbons were considered to be mainly derived from the Jurassic [1,2], Paleogene [3], Neogene [4], and Quaternary [5]. However, the Carboniferous strata were highly mature and eliminated from potential source rocks, as was previously considered well metamorphosed. Since the early 1990s, the Carboniferous strata has gradually received attention in the Qaidam Basin [6-8], and recent research has indicated the Carboniferous rock was formed under warm and humid climatic conditions in the sedimentary environment of a coastal platform facies [7], actually unmetamorphosed [9]. Rapid tectonic subsidence and uplifts occurred in the Carboniferous strata and source rocks have temporarily been at a great burial depth and exposed to high temperatures, but the basin drastically uplifted afterwards [10]. The rapid tectonic subsidence stages were recorded during the periods of Late Devonian-early Carboniferous, Middle Jurassic, and Late Oligocene-Miocene at subsidence rates of 48,10 , and $45 \mathrm{~m} / \mathrm{Ma}$, respectively [11]. The reservoir temperature increased dramatically due to the expeditious burial, reaching $160-170{ }^{\circ} \mathrm{C}$ in the maximum 
burial of the Carboniferous [10,11]. The basin witnessed uplifts during periods of Late Triassic-Jurassic, Late Cenozoic-middle Miocene, and Late Miocene [10].

Carboniferous source rock is mainly composed of dark-colored mudstones, marls, coals, carbonaceous mudstones, and shales and their exploration potential has been gradually revealed $[7,12,13]$. Carboniferous source rock was at the hydrocarbon generation stage as early as the Late Carboniferous based on the burial history [9]. However, hydrocarbon generation suspended due to the uplift and erosion of the Carboniferous controlled by the Hercynian Movement [9]. During the Indochina period, the Carboniferous witnessed uplift and erosion once again. Tectonic subsidence and burial occurred to the Carboniferous of the Dehaling Depression in the period of late Yanshan orogeny when the source rocks were thermally mature for a new round of hydrocarbon generation. In May 2018, straight-well segmented fracturing gas tests (1081-1061 and 820-800 m) were conducted on the Carboniferous Keluke Formation of well Chaiye 2 by the Institute of Geomechanics, Chinese Academy of Geological Sciences. The maximum gas flow rate was $55.52 \mathrm{~m}^{3}$ per hour with guaranteed yields of $145.32 \mathrm{~m}^{3}$ per day, and shale oil was simultaneously produced at a flow rate of $0.65 \mathrm{~m}^{3}$ per day. Shale gas and shale oil, herein, are first discovered in the Paleozoic of Qinghai Tibet Plateau. Source rocks penetrated by well Chaiye 2 are characterized by type III organic matter and are highly mature, with a vitrinite reflectance (Ro) above $1.45 \%$, suggesting the late gas generation stage. However, the liquid oil from well Chaiye 2 shows a normal maturity level.

Few documented studies reported significant discrepancy of thermal maturity between source rocks and liquid hydrocarbons. How can liquid oil be preserved in the highly mature source rocks in the gas generation stage occurring in the Qaidam Basin? Preservation of liquid hydrocarbons in high-maturity source rocks from the Qaidam Basin indicates that source rocks and liquid oil from well Chaiye 2 witnessed differential evolution during thermal maturation. This study was conducted to disclose the preservation of liquid oil in high-maturity source rocks, and to unravel the mechanism of differential evolution between source rocks and expelled hydrocarbons during thermal maturation in the shale reservoir. The present study provides favorable prospects for further hydrocarbon exploration from the highly mature source rocks.

\section{Geological Setting}

Qaidam Basin is characterized by a rhomb-shaped intermontane basin on the northeastern margin of the Tibetan Plateau, surrounded by the Qilian, Kunlun, Altyn, and Alashan Mountains (Figure 1a). The basin was initially an independent craton during the Paleoproterozoic, with basement consisting of mainly metamorphic rocks and carbonate sedimentation. During the periods of the Paleozoic Carboniferous, Qaidam Basin was merely a simple synclinal depression while compressional uplift and erosion occurred during the Permian and Cretaceous. In the Paleogene, the basin was characterized by strike-slip depressions. Compressional folding and depressions were recorded during the periods of the Neogene and Quaternary, and finally featured intrabasinal deformation and uplift [14].

The Carboniferous succession was characterized by marine-terrigenous transitional facies due to the unique depositional environments [14]. The Carboniferous is subdivided into Lower Carboniferous and Upper Carboniferous, and the Keluke Formation belongs to the Upper Carboniferous. The Keluke Formation, with a thickness of 400-700 m, was the main organic-rich source rock section developed in the Carboniferous. Sediments in the Keluke Formation were highly mature and characterized by dark-colored shale, carbonaceous shale, mudstone, muddy siltstone, mudstone, limestone, and shale. Source rock samples in the present study were collected from the Carboniferous Keluke Formation at a depth range of 842-1063 m from well Chaiye 2 in the Delingha Depression (Figure 1b,c). The source rocks were mainly mudstone, black shale, and coaly mudstone, as is shown in the stratigraphic column in Figure 1c. One oil sample was obtained from the Carboniferous mudstone at a depth range of $800-820 \mathrm{~m}$. 


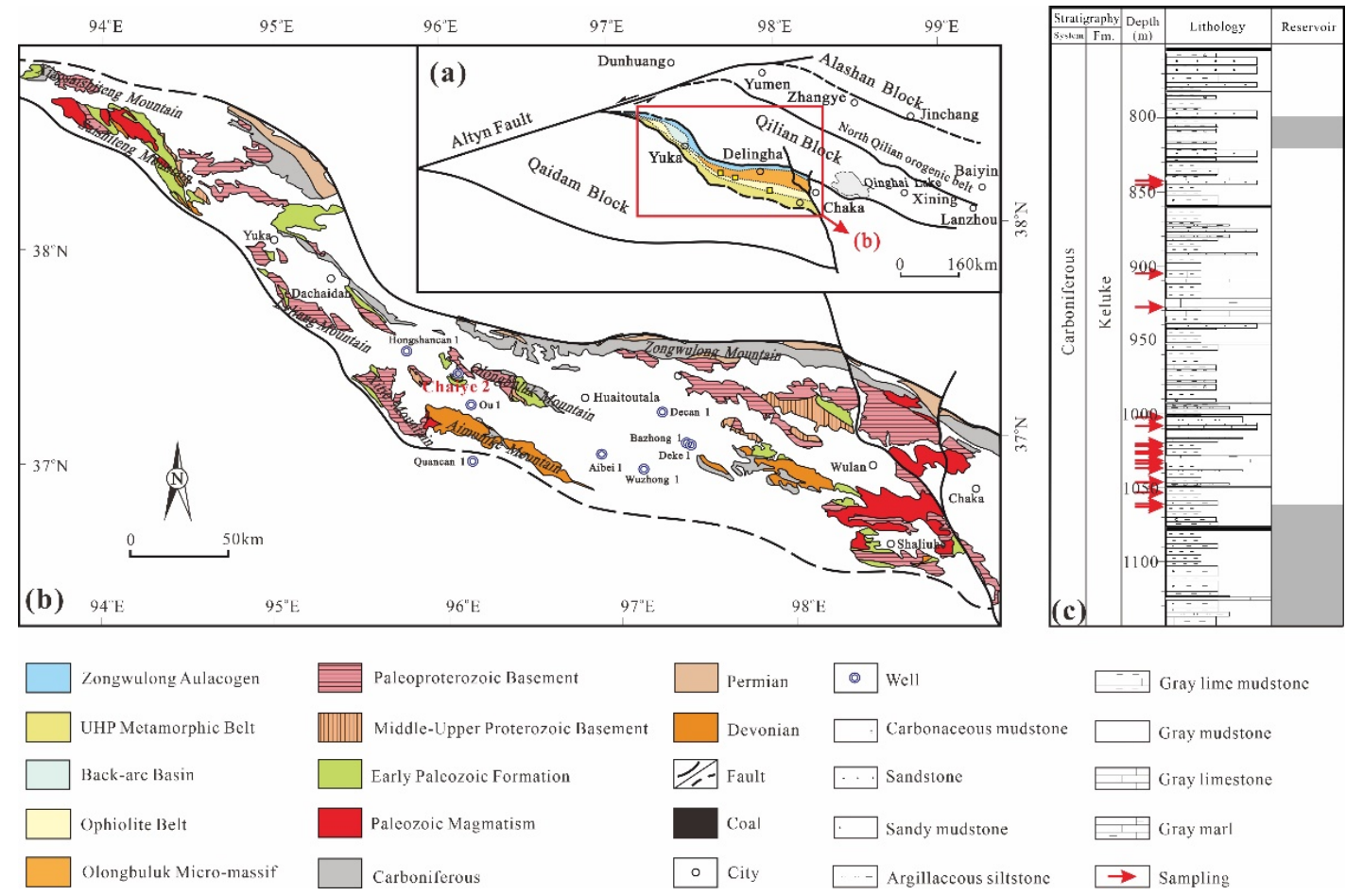

Figure 1. Geological settings: (a) geological map of Qaidam Basin; (b) geological map of Delingha Depression; (c) general stratigraphy of well Chaiye 2 (modified after Wang et al. [10]).

\section{Methods}

\subsection{Vitrinite Reflectance Measurements and Rock-Eval Analyses}

The bulk geochemical characteristics of the studied source rock samples were carried out by Rock-Eval pyrolysis and vitrinite reflectance measurement. Mean random vitrinite reflectance of source rocks was measured at $546 \mathrm{~nm}$ in oil under the operation of an Opton 20 Microscope and Axioplan-Opton microphotometer in the present study.

Rock-Eval pyrolysis was performed on the crushed samples (80-100 mesh) by a Rock-Eval 6 apparatus equipped with a flame ionization and infrared detectors. Detailed pyrolysis procedures and descriptions can be found in Lafargue et al. [15]. The pyrolysis procedure and experiment settings are the same as described by Li et al. [14]. The free hydrocarbons (S1 peak), hydrocarbons generated from kerogen (S2 peak), and $\mathrm{CO}_{2}$ from oxygenated compounds (S3 peak) were measured for bulk geochemical characterization in the present study.

\subsection{Gas Chromatography-Mass Spectrometry (GC-MS) Analysis}

Core samples were pulverized into 80-100 mesh for Soxhlet extraction. Extractable organic matter (EOM) was obtained for hydrocarbon separation in the silica solid phase extraction (SPE) columns. For the purpose of component quantification, internal standards for saturated hydrocarbons (i.e., cholestane- $\mathrm{d}_{4}$, adamantane- $\mathrm{d}_{16}$, phenyldodecane- $\mathrm{d}_{30}$ ) and aromatic hydrocarbons (i.e., naphthalene- $\mathrm{d}_{8}$, phenanthrene- $\mathrm{d}_{10}$, and $1,1^{\prime}$-binaphthyl) were also added in the SPE columns. The sample preparation and operation procedures were the same as described by Wang and Huang [16]. GC-MS analyses of saturated and aromatic fractions were performed using an Agilent 7890B gas chromatograph linked to an Agilent 5977A MSD system with detailed settings described by Wang and Huang [16]. The concentration calculation was based on the peak area without response factor calibration.

\subsection{X-ray Diffraction Mineralogy}

Pulverized samples were analyzed using an X-ray diffraction (XRD) instrument with a $\mathrm{CuKa}$ radiation source to measure the relative content of each mineral composition. The 
voltage of 30-45 kV, current of 20-100 mA, and scanning between 5 and $45^{\circ} \mathrm{C}$ with a speed of $6 \mathrm{dg} / \mathrm{min}$ were used on the whole rock. However, the XRD analysis of clay minerals was conducted with scanning of $0.5-30{ }^{\circ} \mathrm{C}$ and $6 \mathrm{dg} / \mathrm{min}$.

\section{Results}

\subsection{Bulk Geochemical Characterization}

Samples from well Chaiye 2 are rich in organic matters with visually quantified content ranging from $2.6 \%$ to $4.9 \%$ (Table 1 ). The maceral composition of organic matter is mainly composed of vitrinite and inertinite in proportions of $38.5-72.7 \%$ and $27.3-61.5 \%$, respectively, and the kerogen is dominated by type III from the microscopic examination (Table 1).

Table 1. Bulk and maceral compositions of source rock samples from well Chaiye 2.

\begin{tabular}{ccccccccc}
\hline \multirow{2}{*}{ Depth $(\mathbf{m})$} & \multicolumn{3}{c}{ Total Rock (\%) } & \multicolumn{3}{c}{ Organic Composition (\%) } & \multirow{2}{*}{ Kerogen Type } \\
\cline { 2 - 7 } & Total OM & Pyrite & Other Minerals & Sapropelic OM & Liptinite & Vitrinite & Inertinite & \\
\hline 1009 & 3.3 & 4.7 & 92.0 & 0.0 & 0.0 & 72.7 & 27.3 & III \\
1020 & 2.6 & 2.9 & 94.5 & 0.0 & 0.0 & 38.5 & 61.5 & III \\
1027 & 4.9 & 3.3 & 91.8 & 0.0 & 0.0 & 53.1 & 46.9 & III \\
1033 & 3.6 & 2.6 & 93.8 & 0.0 & 0.0 & 52.8 & 47.2 & III \\
1053 & 3.2 & 2.1 & 94.7 & 0.0 & 0.0 & 43.8 & 56.3 & III \\
\hline
\end{tabular}

OM, organic matter.

The total organic carbon (TOC) contents from Rock-Eval pyrolysis have a range of $1.32-31.8 \mathrm{wt} \%$ (Table 2). The free hydrocarbons in the source rocks (S1 peak) are fairly low, ranging from $0.04 \mathrm{mg} / \mathrm{g}$ rock to $1.01 \mathrm{mg} / \mathrm{g}$ rock with an average value of $0.23 \mathrm{mg} / \mathrm{g}$ rock. The hydrocarbons generated from kerogen (S2 peak) vary in a range of $0.44-22.7 \mathrm{mg} / \mathrm{g}$ rock (averaged at $3.81 \mathrm{mg} / \mathrm{g}$ rock). Hence, the total hydrocarbon generation potential, which is represented by $(\mathrm{S} 1+\mathrm{S} 2)$, varies in the range of $0.49-23.7 \mathrm{mg} / \mathrm{g}$ rock. The hydrogen index $(\mathrm{HI}=\mathrm{S} 2 / \mathrm{TOC} \times 100)$ of the studied samples ranges from $9-101 \mathrm{mg} / \mathrm{g}$ TOC (averaged at $41.8 \mathrm{mg} / \mathrm{g}$ TOC) (Table 2$)$, whereas the oxygen index $(\mathrm{OI}=\mathrm{S} 3 / \mathrm{TOC} \times 100)$ varies in the range of $0-10 \mathrm{mg} / \mathrm{g}$ TOC (averaged at $4.9 \mathrm{mg} / \mathrm{g}$ TOC) (Table 2), also suggesting the source rocks were mainly type III kerogens (Figure $2 \mathrm{~b}$ ). The temperature of maximum generation of pyrolytic hydrocarbons (S2), i.e., Tmax values, range from 486 to $502{ }^{\circ} \mathrm{C}$ (Table 2). Solvent extractable organic matter varies from 0.16 to $0.79 \mathrm{mg} / \mathrm{g}$ (averaged at $0.37 \mathrm{mg} / \mathrm{g}$ ) (Table 2). Although the source rocks were dominated by III kerogens (Figure 2b), they were still showed good to excellent potential for hydrocarbon generation (Figure 2a).

Table 2. Results of Rock-Eval pyrolysis and Soxhlet extraction of Chaiye 2 rock samples.

\begin{tabular}{cccccc}
\hline Depth $(\mathbf{m})$ & TOC $(\mathbf{w t} \mathbf{\%})$ & $\left.\operatorname{Tmax}^{\circ}{ }^{\circ} \mathbf{C}\right)$ & HI $(\mathbf{m g} / \mathbf{g})$ & OI (mg/g) & EOM (mg/g Rock) \\
\hline 1009 & 1.58 & 490 & 30 & 6 & 0.25 \\
1020 & 1.8 & 486 & 39 & 8 & 0.28 \\
1025 & 1.32 & 490 & 33 & 9 & 0.18 \\
1027 & 3.28 & 492 & 34 & 5 & 0.21 \\
1033 & 2.86 & 488 & 27 & 5 & 0.41 \\
1037 & 31.8 & 493 & 9 & 0 & 0.56 \\
1047 & 7.18 & 497 & 51 & 3 & 0.79 \\
1053 & 22.4 & 500 & 101 & 1 & 0.61 \\
1061 & 8.61 & 497 & 51 & 2 & 0.16 \\
1063 & 2.13 & 502 & 43 & 10 & 0.25 \\
\hline
\end{tabular}

Vitrinite reflectance is a petrographic method to quantify the percentage of incident light reflected from polished vitrinite particles for thermal maturity assessment [17]. Mean vitrinite reflectance, based on at least 20-100 random measurements in a polished slide of whole rock, is the most common and trustworthy method, which is widely used for 
maturity assessment of source rocks. The studied samples have valid measured vitrinite reflectance points of 21-52 (Table 3). The thermal maturity of source rocks can be classified into immature, early mature, mature, and overmature stages. Immature source rocks with vitrinite reflectance usually below $0.6 \%$ are too cool or have too short a duration for thermal generation of petroleum, whereas they began to generate small amounts of petroleum in the early mature stage $(\sim 0.5-0.6 \%$ Ro) [17]. When the source rocks are mature, organic matter is in the oil-generation window and vitrinite reflectance herein is in a range of $0.6-1.4 \%$. With increasing thermal maturity, source rocks are overmature and it was previously regarded that further oil generation ceased [17]. The mean Ro values increase from $1.45 \%$ to $1.88 \%$ (Table 2), indicating that the studied source rock samples were at the thermally mature to overmature stages.
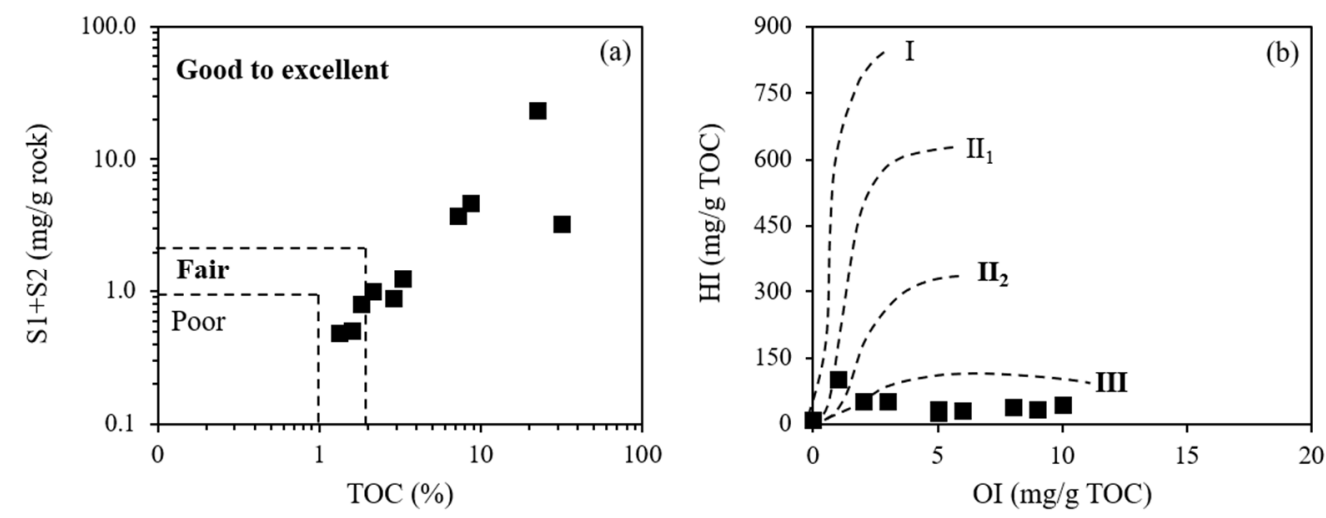

Figure 2. Bulk geochemical data of source rock samples from well Chaiye 2: (a) S1 + S2 vs. TOC; (b) HI vs. OI.

Table 3. Measured Ro values of source rock samples from well Chaiye 2.

\begin{tabular}{cccccc}
\hline \multirow{2}{*}{ Depth (m) } & \multicolumn{3}{c}{ \%o } & $\begin{array}{c}\text { Valid Measured } \\
\text { Points }\end{array}$ & $\begin{array}{c}\text { Standard Deviation } \\
\text { (\%) }\end{array}$ \\
\cline { 2 - 4 } & Minimum & Maximum & Mean & 35 & 0.139 \\
1009 & 1.10 & 1.71 & 1.48 & 21 & 0.100 \\
1020 & 1.35 & 1.63 & 1.48 & 27 & 0.112 \\
1027 & 1.29 & 1.67 & 1.45 & 44 & 0.167 \\
1033 & 1.50 & 2.18 & 1.88 & 52 & 0.174 \\
1053 & 1.41 & 2.07 & 1.76 & & \\
\hline
\end{tabular}

\subsection{Geochemical Characterization of Source Rocks}

Two types of $n$-alkanes distributions can be recognized in the source rock extracts. The first type is characterized by a unimodal distribution with low molecular $n$-alkanes and a relatively high abundance in $n-C_{14}-n-C_{18}$ (Figure 3a). With increasing thermal maturity, high-molecular-weight $n$-alkanes will encounter thermal cracking to form low-molecularweight $n$-alkanes [17]. Hence, the relative abundance of high- and low-molecular-weight $n$-alkanes, i.e., $\sum n-C_{20} 0^{-} / \sum n-C_{21}{ }^{+}$, can be applied for thermal maturation assessment [18]. The values of $\sum n-\mathrm{C}_{20}{ }^{-} / \sum n-\mathrm{C}_{21}{ }^{+}$range from 8.25-27.3 with an average of 15.7 (Table 4), much higher than those in the other types of extracts. The second type shows a bimodal distribution of $n$-alkanes (Figure $3 \mathrm{~b}$ ), also a relatively high abundance in $n-\mathrm{C}_{14}-n-\mathrm{C}_{18}$, with the other peak in $n-\mathrm{C}_{23}$ but less abundant than the dominant peak in $n-\mathrm{C}_{16}$. The values of $\sum n-\mathrm{C}_{20}{ }^{-} / \sum n-\mathrm{C}_{21}{ }^{+}$range from 2.60-5.24 (Table 4). Ratios of pristane/phytane (Pr/Ph), $\mathrm{Pr} / n-\mathrm{C}_{17}$, and $\mathrm{Ph} / n-\mathrm{C}_{18}$ in the two types have similar ranges, $0.89-1.29,0.42-0.58$, and $0.34-0.64$, respectively (Table 4 ). 

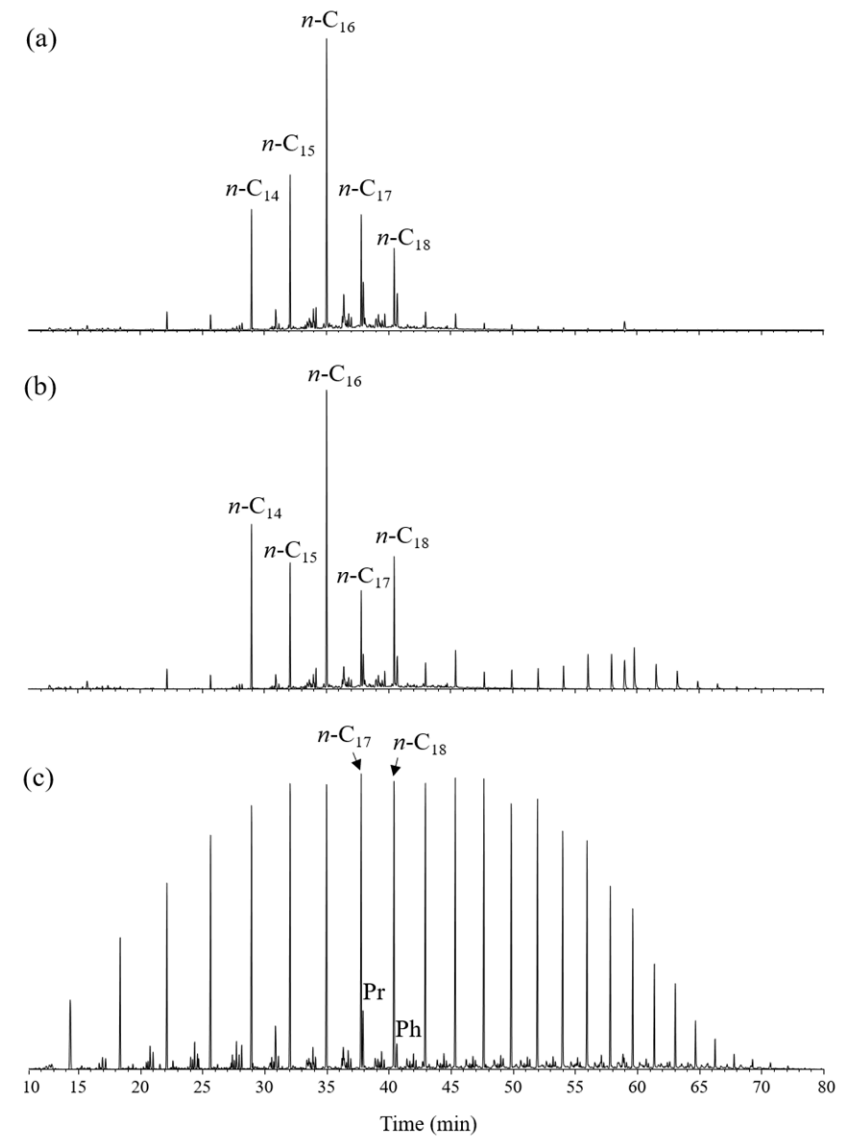

Figure 3. Representative chromatograms of $m / z 85$ showing typical distributions of $n$-alkanes and isoprenoids: (a) source rock extracts from well Chaiye 2 at a depth of $1009 \mathrm{~m}$; (b) source rock extracts from well Chaiye 2 at a depth of 1033 m; (c) crude oil from well Chaiye 2.

Table 4. Geochemical parameters of oil and source rock samples from well Chaiye 2.

\begin{tabular}{|c|c|c|c|c|c|c|c|c|c|c|c|c|c|c|c|}
\hline Sample & $\begin{array}{l}\text { Depth } \\
\text { (m) }\end{array}$ & $\underset{/ \sum n-\mathrm{C}_{20^{-}}}{{ }^{2} n-\mathrm{C}_{21}+}$ & $\mathrm{Pr} / \mathrm{Ph}$ & $\begin{array}{l}\mathrm{Pr} / n- \\
\mathrm{C}_{17}\end{array}$ & $\begin{array}{c}\mathrm{Ph} / n- \\
\mathrm{C}_{18}\end{array}$ & $\begin{array}{c}\text { Ts/(Ts }+ \\
\text { Tm) }\end{array}$ & $\begin{array}{c}20 S /(20 S \\
+20 R)\end{array}$ & $\begin{array}{c}22 S /(22 S \\
+22 R)\end{array}$ & $\begin{array}{c}B \beta(\alpha \alpha \\
+\beta \beta)\end{array}$ & MNR & DNR & TMNr & MPI-3 & MDR & MAI \\
\hline Oil & $\begin{array}{l}800- \\
820\end{array}$ & 1.35 & 2.19 & 0.23 & 0.11 & 0.75 & 0.44 & 0.57 & 0.44 & 1.6 & 6.08 & 0.6 & 0.87 & 3.65 & 53 \\
\hline R1 & 1009 & 27.3 & 1.29 & 0.58 & 0.64 & $\mathrm{n} / \mathrm{a}$ & $\mathrm{n} / \mathrm{a}$ & $\mathrm{n} / \mathrm{a}$ & $\mathrm{n} / \mathrm{a}$ & 3.28 & 17.6 & 0.78 & 3.78 & 22.7 & 74.4 \\
\hline $\mathrm{R} 2$ & 1020 & 11.1 & 1.04 & 0.48 & 0.49 & $\mathrm{n} / \mathrm{a}$ & $\mathrm{n} / \mathrm{a}$ & $\mathrm{n} / \mathrm{a}$ & $\mathrm{n} / \mathrm{a}$ & 3.34 & 20.4 & 0.85 & 4.13 & 32.8 & 77.7 \\
\hline $\mathrm{R} 3$ & 1025 & 15.8 & 1.01 & 0.46 & 0.34 & $\mathrm{n} / \mathrm{a}$ & $\mathrm{n} / \mathrm{a}$ & $\mathrm{n} / \mathrm{a}$ & $\mathrm{n} / \mathrm{a}$ & 3.91 & 22.2 & 0.81 & 4.18 & 26.6 & 72.6 \\
\hline $\mathrm{R} 4$ & 1027 & 16.8 & 1.11 & 0.52 & 0.53 & $\mathrm{n} / \mathrm{a}$ & $\mathrm{n} / \mathrm{a}$ & $\mathrm{n} / \mathrm{a}$ & $\mathrm{n} / \mathrm{a}$ & 3.93 & 28 & 0.89 & 4.62 & 36.7 & 73.3 \\
\hline R5 & 1033 & 2.6 & 1.02 & 0.5 & 0.35 & $\mathrm{n} / \mathrm{a}$ & $\mathrm{n} / \mathrm{a}$ & $\mathrm{n} / \mathrm{a}$ & $\mathrm{n} / \mathrm{a}$ & 4.01 & 25.3 & 0.85 & 4.13 & 33.1 & 59.4 \\
\hline R6 & 1037 & 4.5 & 1.16 & 0.46 & 0.49 & $\mathrm{n} / \mathrm{a}$ & $\mathrm{n} / \mathrm{a}$ & $\mathrm{n} / \mathrm{a}$ & $\mathrm{n} / \mathrm{a}$ & 3.97 & 36.8 & 0.94 & 4.48 & 47.4 & 63.7 \\
\hline R7 & 1047 & 5.24 & 0.92 & 0.44 & 0.38 & $\mathrm{n} / \mathrm{a}$ & $\mathrm{n} / \mathrm{a}$ & $\mathrm{n} / \mathrm{a}$ & $\mathrm{n} / \mathrm{a}$ & 4.12 & 36.2 & 0.92 & 5.28 & 36.9 & 63.5 \\
\hline R8 & 1053 & 22.5 & 1.29 & 0.43 & 0.43 & $\mathrm{n} / \mathrm{a}$ & $\mathrm{n} / \mathrm{a}$ & $\mathrm{n} / \mathrm{a}$ & $\mathrm{n} / \mathrm{a}$ & 3.93 & 36.4 & 0.93 & 4.56 & 44.9 & 61.9 \\
\hline R9 & 1061 & 8.25 & 1.24 & 0.48 & 0.45 & $\mathrm{n} / \mathrm{a}$ & $\mathrm{n} / \mathrm{a}$ & $\mathrm{n} / \mathrm{a}$ & $\mathrm{n} / \mathrm{a}$ & 3 & 15 & 0.78 & 3.39 & 16.8 & 78.2 \\
\hline R10 & 1063 & 8.34 & 0.89 & 0.42 & 0.43 & $\mathrm{n} / \mathrm{a}$ & $\mathrm{n} / \mathrm{a}$ & $\mathrm{n} / \mathrm{a}$ & $\mathrm{n} / \mathrm{a}$ & 3.77 & 23.8 & 0.85 & 4.42 & 29.4 & 74.9 \\
\hline
\end{tabular}

Saturated biomarkers, such as steranes and terpanes, were absent in the source rock extracts, indicating the sediments from well Chaiye 2 were at a highly thermal maturity stage. Alternatively, the aromatic hydrocarbons were in relatively high abundance. The naphthalene and methylnaphthalenes of the source rock extracts could reach thousands to tens of thousands $\mu \mathrm{g} / \mathrm{g}$ EOM, whereas pentamethylnaphthalenes were below $20 \mu \mathrm{g} / \mathrm{g}$ EOM or even absent, indicating the source rock was at the high maturity stages [19]. Numerous maturity parameters derived from alkylnaphthalenes have been established over the years based on the principle of isomerization that the thermally more stable isomer increases relative to the thermally less stable isomer during thermal maturation processes, such as MNR (=2-MN/1-MN) [20], DNR [=(2,6-DMN + 2,7-DMN)/1,5-DMN] [21], TMNr $[=1,3,7-\mathrm{TMN} /(1,3,7+1,2,5)-\mathrm{TMN}]$ [22], TeMNr $[=1,3,6,7-\mathrm{TeMN} /(1,3,6,7-+1,2,5,6-+1,2,3,5-$ 
TeMN)] [22]), and PMNr [=1,2,4,6,7-PMN/(1,2,4,6,7- + 1,2,3,5,6-PMN)] [22]. As risks arise in the highly mature sediments (Ro $>1.0 \%$ ) when TeMNr and PMNr parameters are used for maturity assessment [19], parameters derived from methyl-, dimethyl-, and trimethylsubstituted homologues of naphthalene are accepted as valid thermal maturity parameters for the studied samples (Ro $>1.45 \%$ ). The values of MNR, DNR, and TMNr are in the ranges of 3.00-4.12, 15.0-36.8, and 0.78-0.94, respectively (Figure 4a-c, Table 4).
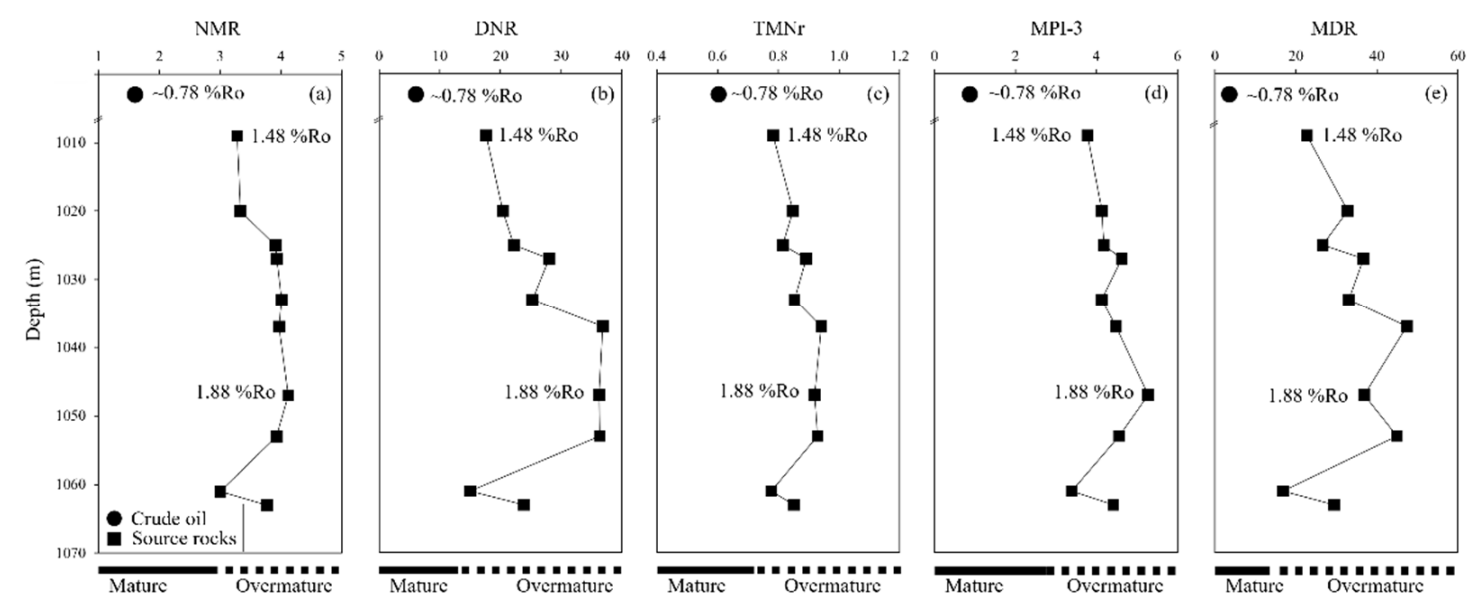

Figure 4. Distribution of thermal maturity parameters derived from aromatic hydrocarbons of the source rock extracts and crude oil. The oil sample is at a depth of 800-820 m. (a) methylnaphthalene ratio (MNR = 2-MN/1-MN); (b) dimethylnaphthalene ratio $[\mathrm{DNR}=(2,6-\mathrm{DMN}+2,7-\mathrm{DMN}) / 1,5-\mathrm{DMN}] ;$ (c) trimethylnaphthalene ratio $[\mathrm{TMNr}=1,3,7-\mathrm{TMN} /(1,3,7+$ 1,2,5) -TMN]; (d) methylphenanthrene index [MPI-3 = (2-MP + 3-MP)/(1-MP + 9-MP)]; (e) methyldibenzothiophene index $(\mathrm{MDR}=4-\mathrm{MDBT} / 1-\mathrm{MDBT})$.

The methylphenanthrene index [MPI-1 = $1.5 \times(2-\mathrm{MP}+3-\mathrm{MP}) /(\mathrm{P}+1-\mathrm{MP}+9-\mathrm{MP})]$ proposed by Radke and Welte [23] is one of the most widely used maturity parameters. However, previous study has shown that MPI- 1 is invalid in the studied samples due to the involvement of phenanthrene in the maturity parameter formula [24,25]. Instead, MPI-3 $[=(2-\mathrm{MP}+3-\mathrm{MP}) /(1-\mathrm{MP}+9-\mathrm{MP})]$ was still valid in assessing the maturity and therefore was applied in the studied samples. This parameter rests on the $\beta$-substituent isomers, which are more thermally stable than the $\alpha$-substituent counterparts. The MPI- 3 values of the source rock extracts range from 3.39 to 5.28 (Figure 4d, Table 4).

As 4-methyldibenzothiophene (4-MDBT) is more thermally stable than 1-MDBT, the methyldibenzothiophene index (MDR = 4-MDBT /1-MDBT) was hence proposed for thermal maturity assessment [26]. The MDR appears to be very sensitive to thermal maturity due to its excellent correlations with vitrinite reflectance [14]. The source rock extracts have MDR values ranging from 16.8-47.4 (Figure 4e, Table 4).

\subsection{Geochemical Characterization of Crude Oil}

The alkane distribution of crude oil is dominated by full series of $n$-alkanes $\left(n-\mathrm{C}_{10}-n\right.$ $\left.\mathrm{C}_{35}\right)$ (Figure 3c). The dominant $n$-alkane $\left(n-\mathrm{C}_{17}\right)$ concentration can reach up to $10,364 \mu \mathrm{g} / \mathrm{g}$ oil. The $\sum n-\mathrm{C}_{20}{ }^{-} / \sum n-\mathrm{C}_{21}{ }^{+}$ratio is 1.35 (Table 4), typical of light oil. There is no odd over even predominance of $n$-alkanes in the crude oil. Isoprenoid alkanes are in much lower abundance than adjacent $n$-alkanes with $\mathrm{Pr} / \mathrm{Ph}, \mathrm{Pr} / n-\mathrm{C}_{17}$, and $\mathrm{Ph} / n-\mathrm{C}_{18}$ ratios of 2.19, 0.23, and 0.11 , respectively (Table 4 ).

Biomarkers, such as terpanes and steranes, were discovered to decrease in abundance with increasing thermal maturity, reaching equilibrium at the early oil generation stage (before $0.8 \%$ Ro) [27,28]. Hence, most parameters derived from steranes and hopanes are only valid at low thermal maturity levels $(\sim 0.6 \%$ Ro) [29]. Steranes and terpanes were abundant in the crude oil sample. The biologically produced $17 \alpha(\mathrm{H})$-trisnorhopane $(\mathrm{Tm})$ was believed to be less stable than $18 \alpha(\mathrm{H})$-trisnorneohopane (Ts) and $\mathrm{Ts} /(\mathrm{Ts}+\mathrm{Tm})$ is 
commonly used as the thermal maturity indicator [17]. The Ts / $\mathrm{Ts}+\mathrm{Tm})$ ratio of the crude oil sample is 0.75 (Table 1). Isomerization at C-22 in $\mathrm{C}_{31} 17 \alpha(\mathrm{H}), 21 \beta(\mathrm{H})$-homohopanes can be also used for thermal maturity assessment by calculating the $22 S /(22 S+22 R)$ ratio, as those with a $22 \mathrm{R}$ configuration are gradually converted to a mixture of $22 \mathrm{R}$ and $22 \mathrm{~S}$ diastereomers with increasing thermal maturity [17]. The ratio of $C_{31} 22 S /(22 S+22 R)$ homohopanes is 0.57 (Table 4 ), approaching the equilibrium value of 0.6 within the oil generation window. The ratios of $C_{29} 20 S /(20 S+20 R)$ and $C_{29} \beta \beta(\alpha \alpha+\beta \beta)$ steranes were approved to be reliable biomarkers for indicating thermal maturity [30,31]. The ratios of $C_{29} 20 S(20 S+20 R)$ and $C_{29} \beta \beta(\alpha \alpha+\beta \beta)$ steranes of the oil sample are both 0.44 (Table 4), suggesting the oil was approaching thermally mature.

Diamondoid hydrocarbons are a class of petroleum compounds with unique thermal stability. Adamantane and diamantane are well-known diamondoid hydrocarbons with adamantane consisting of cyclohexane rings in 'chair' conformation (the diamond subunit) and diamantane containing two subunits. The methyladamantane index [MAI = 1-MA/ $(1-$ MA + 2-MA)] was proposed as a thermal maturity indicator by Chen et al. [32]. The MAI ratios increase from initial values of about $50 \%$ with increasing thermal maturity. In the studied samples, the liquid oil has an MAI value of 53\% while those derived from source rock extracts range from $59 \%$ to $78 \%$ (Table 4 ), suggesting the source rocks were much more thermally mature than the liquid oil.

Diamondoid hydrocarbons are neither destroyed nor created with progressive concentrations during thermal cracking, and hence were regarded as a naturally occurring "internal standard" to estimate the extent of oil cracking [33]. Unlike diamondoid hydrocarbons, the biomarkers that were synthesized by oil precursor organisms, such as bacteria and algae, can be easily cracked. The biomarker concentrations decrease with increasing thermal maturity, and some biomarkers were even eliminated before cracking of the major oil components. For example, the concentration of $\mathrm{C}_{29} 5 \alpha(\mathrm{H}), 14 \alpha(\mathrm{H}), 17 \alpha(\mathrm{H})-$ 24-ethylcholestane 20R sterane drops to near zero at about the point where diamondoid hydrocarbon concentrations begin to rise [33], and hence, was used to distinguish lowmaturity oils derived from biomarker-rich sources from those of high-maturity, highly cracked, and diamondoid-rich sources. The steranes were quite abundant in the liquid oil whereas they were absent in the source rock extracts due to highly thermal maturation. On the contrary, diamondoid hydrocarbons were highly concentrated in the source rock extracts. The summed concentrations of methyldiamantanes (MDs), including 4MD, 1-MD and 3-MD, range from 33 to $252 \mu \mathrm{g} / \mathrm{g}$ EOM and one sample (Ro = 1.88\%) with an abnormal high value of $2419 \mu \mathrm{g} / \mathrm{g}$ EOM. The summed $\mathrm{C}_{29}$ steranes in the liquid oil, including $\mathrm{C}_{29} 5 \alpha(\mathrm{H}), 14 \alpha(\mathrm{H}), 17 \alpha(\mathrm{H})$ 20S sterane, $\mathrm{C}_{29} 5 \alpha(\mathrm{H}), 14 \beta(\mathrm{H}), 17 \beta(\mathrm{H})$ 20R sterane, $\mathrm{C}_{29} 5 \alpha(\mathrm{H}), 14 \beta(\mathrm{H}), 17 \beta(\mathrm{H}) 20 \mathrm{~S}$ sterane, and $\mathrm{C}_{29} 5 \alpha(\mathrm{H}), 14 \alpha(\mathrm{H}), 17 \alpha(\mathrm{H})$ 20R sterane, is $209 \mu \mathrm{g} / \mathrm{g}$ oil in concentration. As is illustrated in Figure 5, the liquid oil was not cracked; however, the source rocks fell into the intense thermal cracking zone with concentrated methyldiamantanes.

All the parameters derived from alkylnaphthalenes, including MNR, DNR, and TMNr of the crude oil, have lower values than those of the source rock extracts. The MNR value of the crude oil is 1.60 whereas those in the source rock extracts range from 3.00-4.12 (Figure 4a). Large discrepancy occurs for the DNR ratio where the value of the crude oil is barely 6.08 but ranges from 15.0-36.8 in the source rock extracts (Figure 4b, Table 4), indicating that the crude oil is less thermally mature than the source rocks. The MPI- 3 and MDR values of the crude oil are 0.87 and 3.65, respectively, while those from the source rock extracts range from 3.39-5.28 and 16.8-47.4, respectively, inferring the source rocks from well Chaiye 2 are more thermally mature than the crude oil. As verified of type III kerogen of the studied samples (Figure $2 b$ ), the equivalent vitrinite reflectance value $(\mathrm{Rc}=0.51+0.073 \times \mathrm{MDR})$ derived from MDR is $0.78 \%$ Ro. The existence of abundant biomarkers, together with the very low diamondoid hydrocarbon concentration in oil, further verifies that the equivalent maturity level in oil is much lower than the measured vitrinite reflectance of the source rocks. 


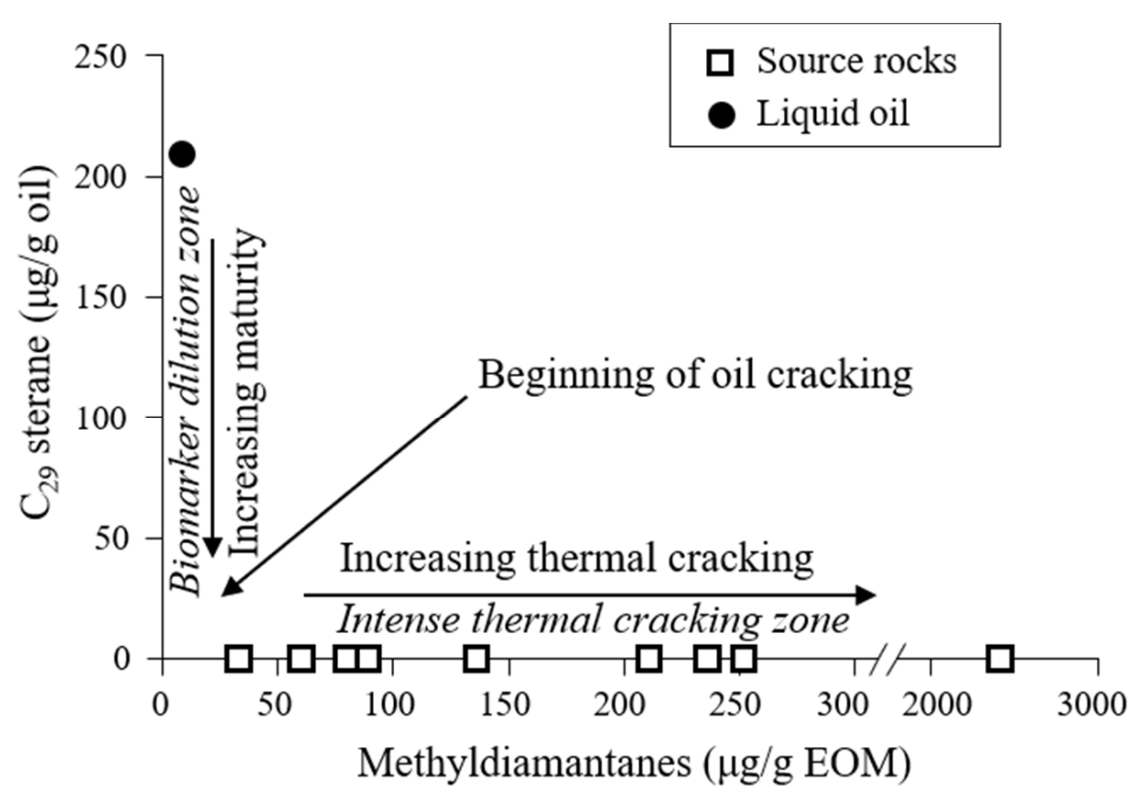

Figure 5. Correlation between the concentrations of methyldiamantanes and $\mathrm{C}_{29}$ steranes in liquid oil and source rock extracts from well Chaiye 2 showing the degree of thermal cracking.

\subsection{Mineralogy}

The mineralogical results (Table 5) show that samples are mainly composed of quartz, calcite, and clay minerals with trace amounts of feldspar, siderite, pyrite, hematite, anatase, or ankerite. Clay minerals and quartz are the predominant compositions in the sedimentary rocks at a depth range of 844.75-1021.7 $\mathrm{m}$ from well Chaiye 2, accounting for 20.6-39.0\% and 47.6-55.9\%, respectively (Table 5). However, samples at the depth of 842.25 and $1031.7 \mathrm{~m}$ have trace amounts of quartz and an absence of clay minerals with an overwhelming predominance of calcite $(>90 \%)$ (Table 5$)$.

Table 5. Quantitative X-ray diffraction analysis of sedimentary rocks from well Chaiye 2.

\begin{tabular}{|c|c|c|c|c|c|c|c|c|c|c|}
\hline \multirow[b]{2}{*}{ Depth (m) } & \multicolumn{10}{|c|}{ Mineral (wt.\%) } \\
\hline & Quartz & $\begin{array}{l}\text { Potassium } \\
\text { Feldspar }\end{array}$ & $\begin{array}{c}\text { Plagioclase } \\
\text { Feldspar }\end{array}$ & Calcite & Siderite & Pyrite & Hematite & Anatase & Ankerite & $\begin{array}{c}\text { Clay } \\
\text { Minerals }\end{array}$ \\
\hline 842.25 & 1.3 & n.d. & n.d. & 95.9 & n.d. & n.d. & 2.8 & n.d. & n.d. & n.d. \\
\hline 844.75 & 50.8 & n.d. & 3.9 & 1.9 & n.d. & 4.4 & n.d. & n.d. & n.d. & 39.0 \\
\hline 905.31 & 52.1 & n.d. & 2.0 & 3.2 & 2.4 & n.d. & n.d. & 2.0 & n.d. & 38.3 \\
\hline 927.65 & 47.6 & n.d. & 1.2 & 19.3 & n.d. & n.d. & n.d. & n.d. & 11.3 & 20.6 \\
\hline 1002.5 & 55.9 & n.d. & 1.2 & 1.9 & 4.9 & n.d. & n.d. & 1.7 & n.d. & 34.4 \\
\hline 1021.7 & 50.1 & 1.3 & 5.6 & 1.3 & 4.0 & 2.1 & n.d. & n.d. & n.d. & 35.6 \\
\hline 1031.7 & 1.5 & n.d. & n.d. & 91.8 & n.d. & n.d. & n.d. & n.d. & 6.7 & n.d. \\
\hline
\end{tabular}

n.d., not detected.

The clay minerals of the samples at a depth range of 844.75-1021.7 m mainly consist of illite, kaolinite, and illite-montmorillonite mixed layers (Table 6). Mixed illitemontmorillonite clay is the predominant composition among the clay minerals, ranging from $41 \%$ to $73 \%$ (Table 6). The montmorillonite content among mixed illite-montmorillonite clay is ranges from $15-30 \%$. Illite and kaolinite account for $15-33 \%$ and $6-41 \%$, respectively (Table 6). Neither smectite nor chlorite were detected in the samples. 
Table 6. Quantitative X-ray diffraction analysis of clay minerals.

\begin{tabular}{ccccccc}
\hline \multirow{2}{*}{ Depth (m) } & \multicolumn{3}{c}{ Clay Mineral (wt.\%) } & \multicolumn{2}{c}{ Montmorillonite Clay (wt.\%) } \\
\cline { 2 - 7 } & Smectite & I/S & Illite & Kaolinite & Chlorite & I/S \\
\hline 844.75 & n.d. & 41 & 18 & 41 & n.d. & 30 \\
927.65 & n.d. & 57 & 27 & 16 & n.d. & 30 \\
905.31 & n.d. & 73 & 15 & 12 & n.d. & 20 \\
1002.5 & n.d. & 61 & 33 & 6 & n.d. & 15 \\
1021.7 & n.d. & 56 & 19 & 25 & n.d. & 25 \\
\hline
\end{tabular}

n.d., not detected. I/S, mixed illite-montmorillonite clay.

\section{Discussion}

Significant maturity inconsistency occurred amongst source rocks and liquid oil from well Chaiye 2. Source rocks from well Chaiye 2 are characterized by high thermal maturity of $1.45-1.88 \%$ Ro. However, the crude oil is at the normal maturity level with calculated vitrinite reflectance of ca. $0.78 \%$. As the source rocks from well Chaiye 2 were deposited as tight mudstone and shale, it is impossible for petroleum and gas to immigrate, and is probably generated and accumulated autochthonously with a short distance of primary migration.

Generally speaking, the crude oil will encounter thermal cracking at reservoir temperatures above $160{ }^{\circ} \mathrm{C}$ (ca. $1.4 \%$ Ro) [34]. How could the liquid oil from well Chaiye 2 be preserved in source rocks of extremely high thermal maturity levels? A reasonable explanation is that liquid oil from well Chaiye 2 was generated at the relatively early thermal maturation stage. However, the thermal evolutions of crude oils and source rocks afterwards were not synchronized due to distinctive impacts of temperature and catalysis on oils and sediments in the shale reservoir.

The thermal maturation of source rocks from well Chaiye 2 has a close relationship with rapid tectonic subsidence and uplifts in the study area [9-11]. Carboniferous source rock was at the hydrocarbon generation stage as early as the Late Carboniferous [9]. Source rocks from well Chaiye 2 were temporarily at a great burial depth in the Carboniferous and herein exposed to high temperatures reaching $160-170{ }^{\circ} \mathrm{C}$ in the maximum burial of the Carboniferous (Figure 6). The basin drastically uplifted afterwards (Figure 6) [10] and hydrocarbon generation suspended due to the uplift and erosion of the Carboniferous controlled by the Hercynian and Indochina movements [9]. Hence, the tectonic subsidence exerted a nonnegligible impact on the thermal maturation of the source rocks, timewise $[9,35]$. The recorded vitrinite was the highest maturity that source rocks had experienced.

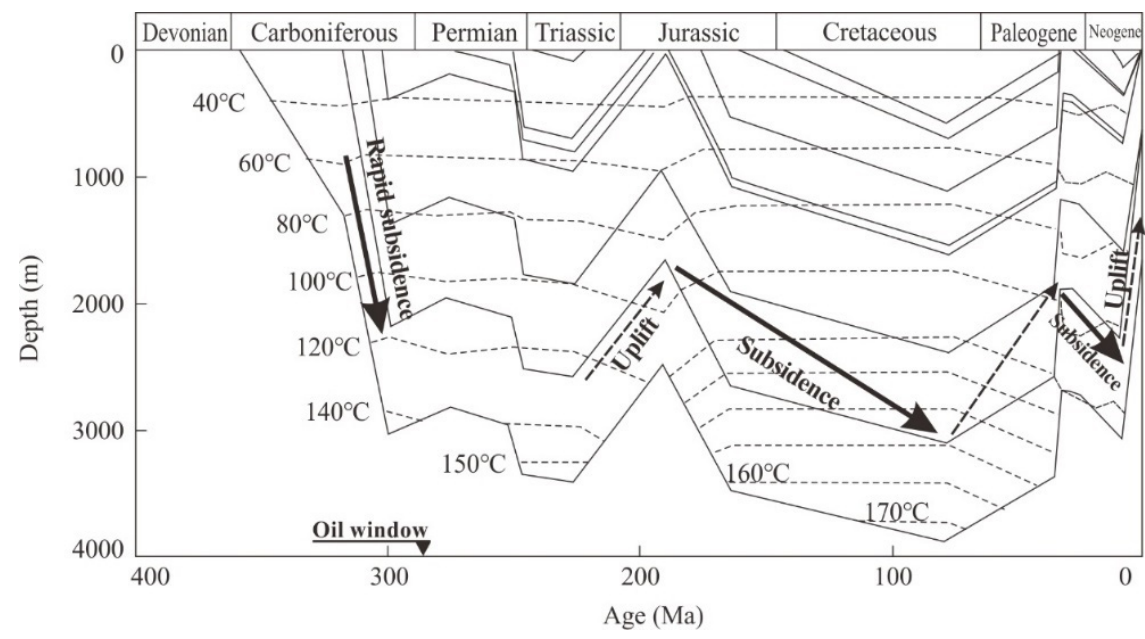

Figure 6. Burial and thermal history of well Chaiye 2 (modified after Wang et al. [10]). 
When sediment with dispersed organic matter is exposed to high temperatures during burial in a subsiding basin, the organic matter is altered continuously. Thermal maturation of petroleum was the transformation from precursor oil to the more thermodynamically stable products of the gas phase and pyrobitumen [36]. High temperatures contribute to thermal cracking of both crude oils and source rocks. Numerous studies have confirmed that oil is stable to $200{ }^{\circ} \mathrm{C}$ [37] given the evidence from field research, laboratory simulations, and theoretical calculations [38-46]. However, the cracking thresholds of source rocks were typically less than $140{ }^{\circ} \mathrm{C}$, much lower than crude oils. Hence, source rock and crude oil in the study area were asynchronous during the thermal maturation, and the source rock was much more thermally mature than crude oil.

Clay catalysis also exerts a significant impact on the differential thermal evolution between oil and source rocks. The kerogen is finely dispersed within the clay matrix of sediments and converted into liquid petroleum hydrocarbons and natural gas with an increasing geothermal gradient during subsequent burial [47-49]. The initial temperature of the liquid petroleum window was recorded as $65^{\circ} \mathrm{C}[50]$, at which significant hydrocarbon generation proceeded, and catalysts in petroleum generation therefrom were disclosed. Grim [51] suggested that the clay minerals in shales concentrate organic constituents by absorption, and later act as catalysts in petroleum conversions. The catalyst clay minerals could be montmorillonite [52,53] and smectite (bentonite) [54,55], which promote carbonium ion reactions $[56,57]$, forming free radicals for further rearrangement and hydrocarbon cracking [58-60]. Hence, clay catalysts play a significant role in hydrocarbon generation from kerogen [61]. Clay minerals and quartz predominated in the compositions in the sedimentary rocks of well Chaiye 2 (Table 5). Clay minerals accounted for 20.6-39.0\% at a depth range of 844.75-1021.7 m, which consisted of illite, kaolinite, and illite-montmorillonite mixed layers (Table 6). A large amount of clay minerals effectively contributed to hydrocarbon cracking in the sedimentary rocks from well Chaiye 2.

However, hydrocarbons are concentrated in crude oils with minor clay minerals. Catalysis of clay minerals exerted a much lesser impact on the thermal cracking of the crude oils than the sediments where clay catalysts are enriched and dispersed. The clay catalysis probably lowered the activation energies for cracking the hydrocarbon in the sediments [62], and therefore proceeded the thermal maturation process in comparison with crude oils. During the long-term geological history, the thermal maturity disparity of petroleum and source rocks enlarged due to the differential thermal evolution. Liquid hydrocarbons, therefore, were preserved in high-maturity source rocks as disclosed in the Qaidam Basin, NW China. The discovery enlarges the hydrocarbon perseveration of maturity ranges in reservoirs, particularly for the unconventional tight formation, which would benefit potential hydrocarbon exploration of highly mature sediments.

\section{Conclusions}

Significant maturity inconsistency occurred amongst source rocks and crude oil from well Chaiye 2. Source rocks from well Chaiye 2 are highly thermally mature with measured Ro values of $1.45-1.88 \%$. Source rock extracts are characterized by low-molecular $n$-alkanes and concentrated diamondoid hydrocarbons due to intense thermal cracking but saturated biomarkers including steranes and terpanes were eliminated. However, crude oil, with a full series of $n$-alkanes $\left(n-C_{10}-n-C_{35}\right)$ and abundant steranes and terpanes, was at a normal maturity level with an estimated vitrinite reflectance of ca. $0.78 \%$. As the crude oil was generated and accumulated autochthonously, the source rocks and crude oil encountered differential thermal evolution based on the preliminary results. The source rocks were exposed to high temperatures and accelerated the thermal maturation due to rapid tectonic subsidence. The vitrinite recorded the highest maturity that source rocks have experienced. Meanwhile, the clay minerals in shales concentrate organic constituents by absorption, and the latter act as catalysts in petroleum conversions. However, hydrocarbons are concentrated in crude oils with minor clay minerals. Crude oil has a lower temperature threshold for thermal cracking than source rocks, causing the disparity of the thermal 
maturity with source rocks in the Qaidam Basin. Differential thermal evolution between crude oil and source rocks enlarges the hydrocarbon perseveration of maturity ranges in reservoirs, particularly for the unconventional tight formation, which provides favorable prospects for further hydrocarbon exploration of highly mature sediments.

Author Contributions: Conceptualization, Q.W. and H.H.; methodology, Q.W. and C.H.; Validation, H.H., C.H. and Q.W.; formal analysis, Q.W. and C.H.; investigation, Q.W.; resources, Z.L.; writingoriginal draft preparation, Q.W.; writing —review \& editing, Q.W. and H.H.; visualization, Q.W.; supervision, H.H.; project administration, H.H. and Z.L.; funding acquisition, H.H. and Z.L. All authors have read and agreed to the published version of the manuscript.

Funding: This work was supported by the government of Canada-funded Canada First Research Excellence Fund (CFREF) program and the National Natural Science Foundation of China (Grant Number 41873049).

Institutional Review Board Statement: Not applicable.

Informed Consent Statement: Not applicable.

Data Availability Statement: Not applicable.

Acknowledgments: We would like to thank Dapeng Liu for providing the stratigraphy of well Chaiye 2 and XRD data. Lloyd Snowdon and Steve Larter are acknowledged for their constructive comments that substantially improved the quality of this manuscript.

Conflicts of Interest: The authors declare no conflict of interest.

\section{References}

1. Jin, Q.; Zha, M.; Zhen, L.; Gao, X.; Peng, D.; Lin, L. Geology and geochemistry of source rocks in the Qaidam Basin, NW China. J. Pet. Geol. 2002, 25, 219-238. [CrossRef]

2. Shao, L.; Li, M.; Li, Y.; Zhang, Y.; Lu, J.; Zhang, W.; Tian, Z.; Wen, H. Geological characeristics and controlling factors of shale gas in the Jurassic of the northern Qaidam Basin. Earth Sci. Front. 2014, 21, 311-322. [CrossRef]

3. Zhang, B.; He, Y.; Chen, Y.; Meng, Q.; Yuan, L. Geochemical charateristics and oil accumulation sigificance of the high quality saline lacustrine source rocks in the western Qaidam Basin, NW China. Acta Pet. Sin. 2017, 38, 1158-1167. [CrossRef]

4. Fu, S.; Ma, D.; Chen, Y.; Zhang, G.; Wu, K. New advance of petroleum and gas exploration in Qaidam Basin. Acta Pet. Sin. 2016, 37, 1-10. [CrossRef]

5. Wang, W.; Liu, W.; Wang, G.; Wang, C. Biodegradation of depositional organic matter and identification of biogenic gas source rocks: An example from the Sanhu depression of Qaidam Basin. Shiyou Xuebao/Acta Pet. Sin. 2016, 37, 318-327. [CrossRef]

6. Cao, J.; Liu, C.; Ma, Y.; Li, Z.; Yang, Y.; Wang, G.; Peng, B.; Zhang, X.; Dun, C. Geochemical characteristics and genesis of shale gas for Carboniferous marine-continental transitional facies coal measure strata in Eastern Qaidam Basin. Earth Sci. Front. 2016, 23, 158-166. [CrossRef]

7. Liu, C.; Ma, Y.; Zhou, G.; Yin, C.; Du, J.; Gong, W.; Fan, T.; Liu, W.; Xu, Y.; Zhang, Q. Evidence for the Carboniferous hydrocarbon generation in Qaidam Basin. Acta Pet. Sin. 2012, 33, 925-931.

8. Xu, Y.H.; Lu, M.; Wen, Z.G. Discovery of carboniferous oil seepage in qaidam basin and its geological significance. Pet. Sci. Technol. 2014, 32, 1704-1712. [CrossRef]

9. Li, Z.; Peng, B.; Ma, Y.; Hu, J.; Wei, X.; Ma, L.; Fang, X.; Yang, Y.; Liu, K. Progress of Carboniferous oil and gas survey in Qaidam Basin. Geol. Surv. China 2019, 6, 79-87. [CrossRef]

10. Wang, L.; Zongxing, L.I.; Liu, C.; Peng, B.; Fang, X.; Yuan, G. Thermal History since the Paleozoic in the Eastern Qaidam Basin, Northwest China. Acta Geol. Sin. 2019, 93, 297-306. [CrossRef]

11. Li, Z.; Qiu, N.; Ma, Y.; Guo, Y.; Xiao, Y.; Zhao, W. The tectono-thermal evolution in the eastern Qaidam Basin, Northwest China since the Paleozoic. Earth Sci. Front. 2017, 24, 157-167. [CrossRef]

12. Gao, J.; Li, Z. Water saturation-driven evolution of helium permeability in Carboniferous shale from Qaidam Basin, China: An experimental study. Mar. Pet. Geol. 2018, 96, 371-390. [CrossRef]

13. Ma, Y.; Yin, C.; Liu, C.; Du, J.; Cheng, H.; Fan, T. The progress of Carboniferous oil and gas investigation and assessment in Qaidam Basin. Diqiu Xuebao (Acta Geosci. Sin.) 2012, 33, 135-144.

14. Li, Z.; Huang, H.; He, C.; Fang, X. Maturation impact on polyaromatic hydrocarbons and organosulfur compounds in the Carboniferous Keluke Formation from Qaidam Basin, NW China. Energy Fuels 2019, 33, 4115-4129. [CrossRef]

15. Lafargue, E.; Marquis, F.; Pillot, D. Rock-Eval 6 applications in hydrocarbon exploration, production, and soil contamination studies. Rev. Inst. Fr. Pet. 1998, 53, 421-437. [CrossRef]

16. Wang, Q.; Huang, H. Perylene preservation in an oxidizing paleoenvironment and its limitation as a redox proxy. Palaeogeogr. Palaeoclimatol. Palaeoecol. 2021, 562, 110104. [CrossRef] 
17. Peters, K.E.; Walters, C.C.; Moldowan, J.M. Biomarkers and Isotopes in Petroleum Exploration and Earth History. In The Biomarker Guide; Cambridge University Press: Cambridge, UK, 2005; Volume 2, ISBN 0521837634.

18. Wang, Q.; Huang, H.; Li, Z. Mixing scenario of a vagarious oil in the Dongying Depression, Bohai Bay Basin. Fuel 2021, $294,120589$. [CrossRef]

19. Wang, Q.; Huang, H.; Zheng, L. Thermal maturity parameters derived from tetra-, penta-substituted naphthalenes and organosulfur compounds in highly mature sediments. Fuel 2021, 288, 119626. [CrossRef]

20. Radke, M.; Welte, D.H.; Willsch, H. Geochemical study on a well in the Western Canada Basin: Relation of the aromatic distribution pattern to maturity of organic matter. Geochim. Cosmochim. Acta 1982, 46, 1-10. [CrossRef]

21. Alexander, R.; Kagi, R.I.; Rowland, S.J.; Sheppard, P.N.; Chirila, T.V. The effects of thermal maturity on distributions of dimethylnaphthalenes and trimethylnaphthalenes in some Ancient sediments and petroleums. Geochim. Cosmochim. Acta 1985, 49, 385-395. [CrossRef]

22. Van Aarssen, B.G.K.; Bastow, T.P.; Alexander, R.; Kagi, R.I. Distributions of methylated naphthalenes in crude oils: Indicators of maturity, biodegradation and mixing. Org. Geochem. 1999, 30, 1213-1227. [CrossRef]

23. Radke, M.; Welte, D.H. The methylphenanthrene index (MPI): A maturity parameter based on aromatic hydrocarbons. Adv. Org. Geochem. 1981, 1983, 504-512.

24. He, C.; Huang, H.; Wang, Q.; Li, Z. Correlation of maturity parameters derived from methylphenanthrenes and methyldibenzothiophenes in the Carboniferous source rocks from Qaidam Basin, NW China. Geofluids 2019, 2019, 5742902. [CrossRef]

25. Szczerba, M.; Rospondek, M.J. Controls on distributions of methylphenanthrenes in sedimentary rock extracts: Critical evaluation of existing geochemical data from molecular modelling. Org. Geochem. 2010, 41, 1297-1311. [CrossRef]

26. Radke, M.; Welte, D.H.; Willsch, H. Maturity parameters based on aromatic hydrocarbons: Influence of the organic matter type. Org. Geochem. 1986, 10, 51-63. [CrossRef]

27. Van Graas, G.W. Biomarker maturity parameters for high maturities: Calibration of the working range up to the oil/condensate threshold. Org. Geochem. 1990, 16, 1025-1032. [CrossRef]

28. Wilhelms, A.; Larter, S. Shaken but not always stirred. Impact of petroleum charge mixing on reservoir geochemistry. Geol. Soc. Spec. Publ. 2004, 237, 27-35. [CrossRef]

29. Mackenzie, A.S.; Maxwell, J.R. Assessment of thermal maturation in sedimentary rocks by molecular measurements. Org. Matur. Stud. Foss. Fuel Explor. 1981, 239-254. Available online: https:/ / pascal-francis.inist.fr/vibad/index.php?action=getRecordDetail\& idt=PASCALGEODEBRGM8220126224 (accessed on 20 September 2021).

30. Mackenzie, A.S.; Patience, R.L.; Maxwell, J.R.; Vandenbroucke, M.; Durand, B. Molecular parameters of maturation in the Toarcian shales, Paris Basin, France-I. Changes in the configurations of acyclic isoprenoid alkanes, steranes and triterpanes. Geochim. Cosmochim. Acta 1980, 44, 1709-1721. [CrossRef]

31. Seifert, W.K.; Moldowan, J.M. The effect of thermal stress on source-rock quality as measured by hopane stereochemistry. Phys. Chem. Earth 1980, 12, 229-237. [CrossRef]

32. Chen, J.; Fu, J.; Sheng, G.; Liu, D.; Zhang, J. Diamondoid hydrocarbon ratios: Novel maturity indices for highly mature crude oils. Org. Geochem. 1996, 25, 179-190. [CrossRef]

33. Dahl, J.E.; Moldowan, J.M.; Peters, K.E.; Claypool, G.E.; Rooney, M.A.; Michael, G.E.; Mello, M.R.; Kohnen, M.L. Diamondoid hydrocarbons as indicators of natural oil cracking. Nature 1999, 399, 54-57. [CrossRef]

34. Pepper, A.S.; Dodd, T.A. Simple kinetic models of petroleum formation. Part II: Oil-gas cracking. Mar. Pet. Geol. 1995, 12, 321-340. [CrossRef]

35. Wang, L.; Li, Z.; Liu, C.; Peng, B.; Hu, J.; Peng, X.; Liu, L. The carboniferous source rock maturity evolution in the delingha depression in the Qaidam Basin, northwest China. J. Geomech. 2019, 25, 370-381. [CrossRef]

36. Takach, N.E.; Barker, C.; Kemp, M.K. Stability of natural gas in the deep subsurface: Thermodynamic calculation of equilibrium compositions. Am. Assoc. Pet. Geol. Bull. 1987, 71, 322-333. [CrossRef]

37. Hill, R.J.; Tang, Y.; Kaplan, I.R. Insights into oil cracking based on laboratory experiments. Org. Geochem. 2003, $34,1651-1672$. [CrossRef]

38. Domine, F. Kinetics of Hexane Pyrolysis at Very High Pressures. 1. Experimental Study. Energy Fuels 1989, 3, 89-96. [CrossRef]

39. Dominé, F. High pressure pyrolysis of n-hexane, 2,4-dimethylpentane and 1-phenylbutane. Is pressure an important geochemical parameter? Org. Geochem. 1991, 17, 619-634. [CrossRef]

40. Dominé, F.; Marquaire, P.M.; Muller, C.; Côme, G.M. Kinetics of Hexane Pyrolysis at Very High Pressures. 2. Computer Modeling. Energy Fuels 1990, 4, 2-10. [CrossRef]

41. Dominé, F.; Dessort, D.; Brévart, O. Towards a new method of geochemical kinetic modelling: Implications for the stability of crude oils. Org. Geochem. 1998, 28, 597-612. [CrossRef]

42. Dominé, F.; Enguehard, F. Kinetics of hexane pyrolysis at very high pressures-3. Application to geochemical modeling. Org. Geochem. 1992, 18, 41-49. [CrossRef]

43. Mango, F.D. The origin of light cycloalkanes in petroleum. Geochim. Cosmochim. Acta 1990, 54, 23-27. [CrossRef]

44. Price, L.C.; Clayton, J.L.; Rumen, L.L. Organic geochemistry of the $9.6 \mathrm{~km}$ Bertha Rogers No. 1. well, Oklahoma. Org. Geochem. 1981, 3, 59-77. [CrossRef]

45. Price, L.C. Origins, characteristics, controls, and economic viabilities of deep-basin gas resources. Chem. Geol. 1995, 126, 335-349. [CrossRef] 
46. Schenk, H.J.; di Primio, R.; Horsfield, B. The conversion of oil into gas in petroleum reservoirs. Part 1: Comparative kinetic investigation of gas generation from crude oils of lacustrine, marine and fluviodeltaic origin by programmed-temperature closed-system pyrolysis. Org. Geochem. 1997, 26, 467-481. [CrossRef]

47. Stevens, N.P.; Bray, E.E.; Evans, E.D. Hydrocarbons in sediments of Gulf of Mexico. Am. Assoc. Pet. Geol. Bull. 1956, 40, 975-983. [CrossRef]

48. Bray, E.E.; Evans, E.D. Distribution of n-paraffins as a clue to recognition of source beds. Geochim. Cosmochim. Acta 1961, 22, 2-15. [CrossRef]

49. Cooper, J.E. Fatty acids in recent and ancient sediments and petroleum reservoir waters. Nature 1962, 193, 744-746. [CrossRef]

50. Pusey, W.C. Paleotemperatures in the Gulf Coast Using the Esr-Kerogen Method. Gcags Trans. 1973, 23, $195-202$.

51. Grim, R.E. Relation of clay mineralogy to origin and recovery of petroleum. Am. Assoc. Pet. Geol. Bull. 1947, 31. [CrossRef]

52. Galwey, A.K. Reactions of alcohols and of hydrocarbons on montmorillonite surfaces. J. Catal. 1970, 19, 330-342. [CrossRef]

53. Galwey, A.K. The rate of hydrocarbon desorption from mineral surfaces and the contribution of heterogeneous catalytic-type processes to petroleum genesis. Geochim. Cosmochim. Acta 1972, 36, 1115-1130. [CrossRef]

54. Brooks, B.T. Evidence of Catalytic Action in Petroleum Formation. Ind. Eng. Chem. 1952, 44, 2570-2577. [CrossRef]

55. Henderson, W.; Eglinton, G.; Simmonds, P.; Lovelock, J.E. Thermal alteration as a contributory process to the genesis of petroleum. Nature 1968, 219, 1012-1016. [CrossRef]

56. Greensfelder, B.S.; Voge, H.H.; Good, G.M. Catalytic and Thermal Cracking of Pure Hydrocarbons: Mechanisms of Reaction. Ind. Eng. Chem. 1949, 41, 2573-2584. [CrossRef]

57. Thomas, C.L. Chemistry of Cracking Catalysts. Ind. Eng. Chem. 1949, 41, 2564-2573. [CrossRef]

58. Solomon, D.H.; Rosser, M.J. Reactions catalyzed by minerals. Part I. Polymerization of styrene. J. Appl. Polym. Sci. 1965, 9, 1261-1271. [CrossRef]

59. Solomon, D.H. Clay minerals as electron acceptors and/or electron donors in organic reactions. Clays Clay Miner. 1968, 16, 31-39. [CrossRef]

60. Theng, B.K.G. Mechanisms of formation of colored clay-organic complexes. A review. Clays Clay Miner. 1971, 19, 383-390. [CrossRef]

61. Johns, W.D. Clay mineral catalysis and petroleum generation. Annu. Rev. Earth Planet. Sci. 1979, 7, 183-198. [CrossRef]

62. Connan, J. Time-Temperature Relation in Oil Genesis. Am. Assoc. Pet. Geol. Bull. 1974, 56, 2068-2071. 